Ethiopian Journal of Environmental Studies \& Management 8(5): 556 - 569, 2015.

ISSN:1998-0507

doi: http://dx.doi.org/10.4314/ejesm.v8i5.9

Submitted: March 04, 2015

Accepted: July 09, 2015

\title{
PREDICTING TOXIC HEAVY METAL MOVEMENTS IN UPPER SANYATI CATCHMENT IN THE MIDLANDS PROVINCE IN ZIMBABWE
}

\author{
*MADEBWE, V., ${ }^{1}$ MUNODAWAFA, A., ${ }^{2}$ MUGABE, F. ${ }^{3}$ AND MADEBWE, ${ }^{1}{ }^{1}$ \\ ${ }^{1}$ Department of Geography and Environmental Studies, Midlands State University, Gweru, \\ Zimbabwe \\ ${ }^{2}$ Department of Lands and Water Resources Management, Midlands State University, Gweru, \\ Zimbabwe \\ ${ }^{3}$ Research and Resource Mobilization Directorate, Chinhoyi University of Technology, \\ Chinhoyi, Zimbabwe
}

\begin{abstract}
The study assessed toxic heavy metal concentrations in the upper Sanyati catchment in the Midlands Province in Zimbabwe and predicted their movements and potential impacts on ground water quality. Topographic surveying was used to determine borehole locations, elevations, hydraulic conductivity and water yields. Monthly ground water samples were analyzed to determine concentrations of $\mathrm{Cr}, \mathrm{Pb}, \mathrm{Cd}$ and $\mathrm{Ni}$ for a period of two-years. The results obtained for the wet season showed mean concentration levels of $\mathrm{Cr}, \mathrm{Pb}, \mathrm{Cd}$ and $\mathrm{Ni}$ at 0.25, $0.015,0.042$ and $0.031 \mathrm{mg} / \mathrm{L}$ respectively. Dry season mean concentration levels for $\mathrm{Cr}, \mathrm{Pb}, \mathrm{Cd}$ and $\mathrm{Ni}$ were $0.15,0.07,0.06$ and $0.025 \mathrm{mg} / \mathrm{L}$ respectively. Water samples from boreholes located in areas where mining, mineral processing and agricultural activities were dominant, yielded the highest values of toxic heavy metals. Dilution Attenuation Factor (DAF) for each toxic heavy metal was calculated to observe metal behaviour along the contaminant path for each season. The results showed seasonal variation in the spatial distribution of each toxic heavy metal during the wet season between October to March and during the dry season between April to September. Overall, research results showed that concentrations of $\mathrm{Cr}, \mathrm{Pb}, \mathrm{Cd}$ and $\mathrm{Ni}$ were above the standard limits set by the World Health Organization.
\end{abstract}

Key Words: Heavy metals; Hydraulic conductivity; Ground water transportation; Contamination; Attenuation; Photometry.

\section{Introduction}

Geochemically, ground water is important in the distribution and redistribution of chemical components since it's a major terrestrial compartment in the water cycle (Worral et al., 2002). Ground water contamination is predominantly indirect because the pollutants pass through different layers of the soil. Generally, toxic heavy metal pollution in ground water is dependent upon the state of the sub-surface environment over which it is passing through (Brassington, 1988). Thus in unsaturated sub-systems, toxic heavy metal contamination of ground water supplies is due to the greater degree of aerobic degradation, adsorption and ion exchange of organics and in-organics. On the other hand in saturated zones heavy metal contamination of ground water is generally

*Corresponding author: Madebwe, V.

Email: madebwev@msu.ac.zw 
attributed to physical chemical processes that include; dilution, $\mathrm{pH}$ buffering and precipitation, hydrolysis, oxidationreduction reactions, mechanical filtration, volatilization, radioactive decay and sorption (EPA 1994). In other cases when soils are polluted to a degree where their adsorptive retention power is exceeded the toxic heavy metal contaminants find their way into ground water supplies (Luo et al., 2009).

In Zimbabwe, the ground waterecosystem interaction studies, with particular reference to toxic heavy metal loading and attenuation have not yielded quantitative evidence and merit research (ZINWA, 2010). This research focused on ground water which refers to the water from rain or other forms of precipitation that soaks into the ground and moves downwards to fill cracks and other openings in the soil or rocks (Todd, 1980). Toxic heavy metals in this research refer to any metallic chemical element that has a specific gravity of 6 , among them cadmium, mercury, lead, chromium, nickel and copper which are highly toxic in minute quantities when released into the environment (Basta et al., 2005). When toxic heavy metals find their way into ground water resources, their contamination levels vary according to number of sites, intensity, strength, $\mathrm{pH}$ and temperature at either point or non point sources. Contamination levels are also dependent upon the capacity of the soil to absorb and degrade chemical elements (IUCN, 1994; Harter, 2005).
Ground water quality mapping is thus important for understanding the distribution and abundance of elements and the changes in local cycles due to spreading contaminants (Bolan et al., 2004). Human populations dominate the trace element cycle through environmental enrichment with orders higher than in the natural systems (Eary and Rai, 1987; Cooper, 2002; Klee and Graedel, 2004). An appraisal of human activities in space and time is essential for predicting trends and variations of toxic heavy metals in ground water resources. Quantitative evidence on toxic heavy metal loads will assist in determining the suitability of ground in upper Sanyati Catchment for human consumption.

\section{Study Area}

The study was conducted in upper Sanyati catchment which is in the Midlands Province in the Highveld of Zimbabwe (Figure 1). The study area is located between $29^{\circ} 42^{\prime \prime}$ and $30^{\circ} 23^{\prime \prime}$ East of the Greenwich Meridian and $19^{\circ} 10^{\prime \prime}$ and $19^{\circ} 39^{\prime \prime}$ south of the Equator. It is located at an altitude of 1200 metres above mean sea level. The topography of upper Sanyati catchment is characterized by peneplains. It gently slopes towards the northwest along an area drained by Sebakwe River and its tributaries.

The study area is a sub-catchment of the upper Sanyati Catchment which covers approximately $168 \mathrm{~km}^{2}$ in area. It extends from $10 \mathrm{~km}$ North East of Gweru City to Lalapanzi $42 \mathrm{~km}$ East as shown in Figure 1. 


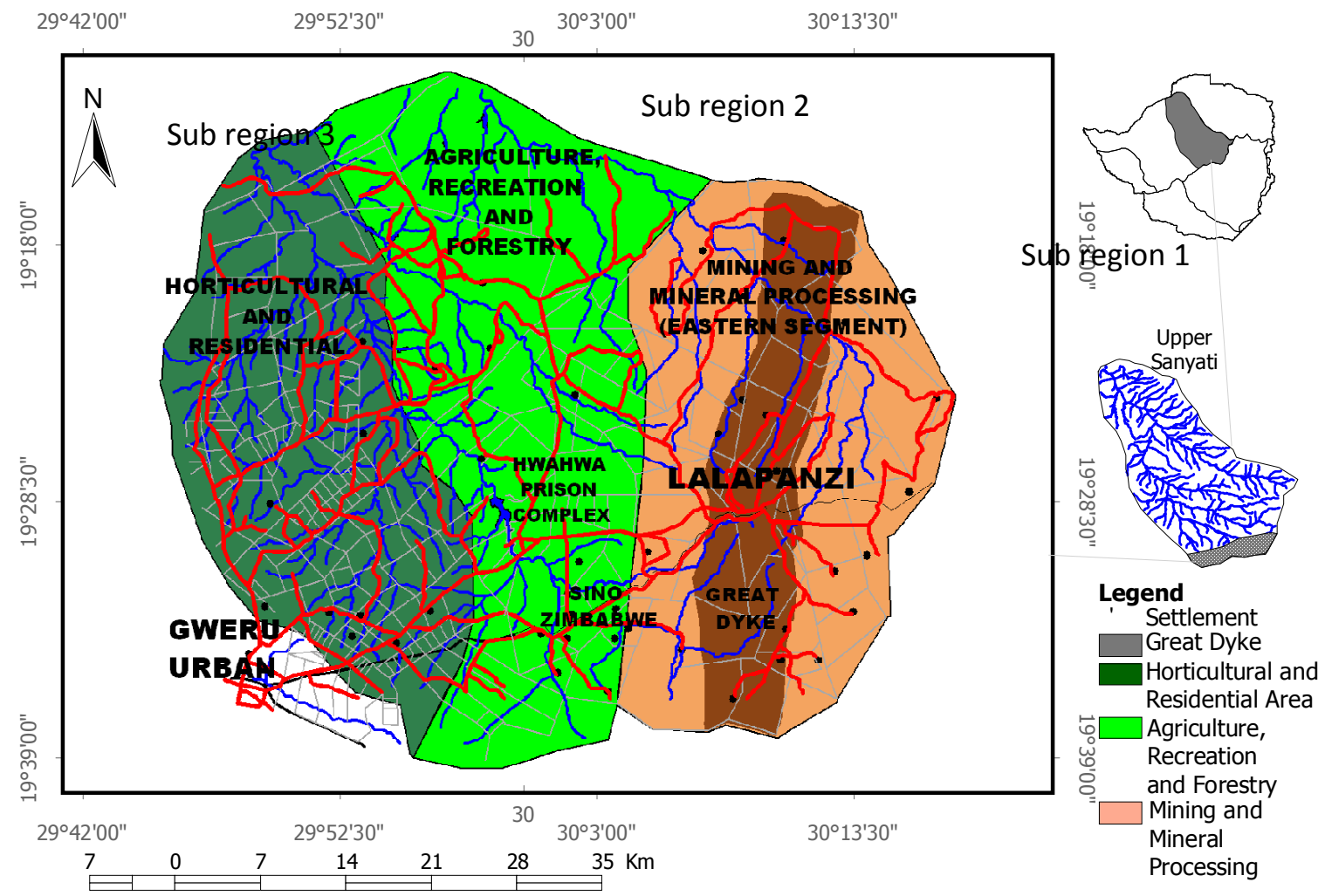

Figure 1: Sub-section of Upper Sanyati Catchment showing physiographic features and land uses.

Source: Geography and Environmental Studies Department, Midlands State University, 2012.

The study area is divided into three subregions based on land use. Sub-region 1 covers the eastern segment where mining and mineral processing activities are predominant in areas around Lalapanzi. It is part of the Tokwean terrain composed mainly of gneissic rocks and structurally complex inliers of possibly older greenstone belts of the Zimbabwean craton. It is the intruded part of the Great Dyke whose geologic setting is made up of a number of distinct tectonostratigraphic terrain assemblages arising from varying geologic events (Wilson and Prendergast, 2001). The greenstone belt is overlain uncomfortably by an assemblage of mafic and felsic volcanic rocks and conglomerates, sandstones, shale and limestone (Kusky, 1998). Lineaments interpreted from Land sat TM imagery and aerial photographs represent faults, joints and dykes of several ages. These fissured rocks lack primary porosity. Aquifers only occur within the weathered regolith and fractured bedrock (Wright, 1997). Ground water level depths range from 3 metres below ground level in summer to more than 90 metres below ground surface during the dry period.

Sub-region 2 covers the central section of study area that is predominantly under limestone and dolomite bedrock. Quarrying and cement manufacturing as well as small to medium scale agricultural activities are the dominant human activities. Aquifer transmissivity and hydraulic conductivity values range between 0.3 and 0.9 cubic metres per second (ZINWA, 2009). Field evidence shows that average water table fluctuations range between 3 and 5 metres between dry and wet seasons probably due 
to continuous recharges from Kwekwe River and its tributaries.

Sub-region 3 is the western segment of the study area whose rock outcrops are predominantly hornblende-biotitic gneisses. These rock formations are more often intruded by granites, pegmatite and quartz veins as well as gabbros and dolerite rock types. Table 1 shows ground water sampling sites by sub-region, main rock outcrops, borehole depth, locations, elevations and detected toxic heavy metals and silicate minerals.

Table 1: Ground water sampling sites by sub-region, main rock outcrops, borehole depth, locations, elevations and detected toxic heavy metals and silicate minerals.

\begin{tabular}{|c|c|c|c|c|c|c|}
\hline $\begin{array}{l}\text { Dominant Rock } \\
\text { Type by Sub- } \\
\text { region }\end{array}$ & $\begin{array}{l}\text { Borehole } \\
\text { Number and } \\
\text { Depth in } \\
\text { metres } \\
\end{array}$ & $\begin{array}{l}\text { Location } \\
\text { GPS } \\
\text { Reading }\end{array}$ & $\begin{array}{l}\text { Elevation } \\
\text { above sea } \\
\text { level } \\
\text { (metres) }\end{array}$ & $\begin{array}{l}\text { Mean } \\
\text { Temperature } \\
{ }^{\circ} \mathrm{C} \\
\end{array}$ & $\begin{array}{l}\text { mean } \\
\mathrm{pH}\end{array}$ & $\begin{array}{l}\text { Silicate } \\
\text { minerals/ } \\
\text { Trace } \\
\text { elements }\end{array}$ \\
\hline $\begin{array}{l}\text { Great Dyke- } \\
\text { Chromite (1) }\end{array}$ & $1 / 42$ & $\begin{array}{l}0204577 / 78 \\
58814\end{array}$ & 1480 & 28 & 6.3 & $\begin{array}{l}\mathrm{Cr}, \quad \mathrm{Ni}, \mathrm{Pb}, \\
\mathrm{Fe}, \mathrm{Ca}, \mathrm{Mg}\end{array}$ \\
\hline $\begin{array}{l}\text { Great Dyke- } \\
\text { Chromite (1) }\end{array}$ & $2 /+40$ & $\begin{array}{l}0203943 / 78 \\
59546\end{array}$ & 1497 & 22 & 6.9 & $\begin{array}{l}\mathrm{Cr}, \mathrm{Ni}, \mathrm{Pb} \\
\mathrm{Fe}, \mathrm{Ca}, \mathrm{Mg}\end{array}$ \\
\hline $\begin{array}{l}\text { Great Dyke- } \\
\text { Chromite (1) }\end{array}$ & $3 /+40$ & $\begin{array}{l}0203284 / 78 \\
60086\end{array}$ & 1499 & 23 & 6.5 & $\begin{array}{l}\mathrm{Cr}, \mathrm{Ni}, \mathrm{Fe}, \\
\mathrm{Ca}, \mathrm{Mg}\end{array}$ \\
\hline $\begin{array}{l}\text { Jarosite } \\
\text { (Carbonated) (2) }\end{array}$ & $4 / 40$ & $\begin{array}{l}0189199 / 78 \\
50373\end{array}$ & 1390 & 25 & 7.2 & $\begin{array}{l}\text { As, } \mathrm{Pb}, \mathrm{Cd}, \\
\mathrm{Ca}, \mathrm{Mg}\end{array}$ \\
\hline $\begin{array}{l}\text { Carbonated } \\
\text { igneous rocks } \\
\text { (2) }\end{array}$ & $5 /+40$ & $\begin{array}{l}0189509 / 78 \\
52399\end{array}$ & 1375 & 25 & 6.9 & $\begin{array}{l}\mathrm{Fe}, \mathrm{Cd}, \mathrm{Pb}, \\
\mathrm{Ni}\end{array}$ \\
\hline $\begin{array}{l}\text { Carbonated } \\
\text { igneous rocks } \\
\text { (2) }\end{array}$ & $6 /+40$ & $\begin{array}{l}0185445 / 78 \\
56760\end{array}$ & 1358 & 26 & 7 & $\begin{array}{l}\mathrm{Fe}, \mathrm{Cd}, \mathrm{Pb}, \\
\mathrm{Ni}, \mathrm{Mg}\end{array}$ \\
\hline $\begin{array}{l}\text { Alluvial } \\
\text { deposits/ } \\
\text { decomposed } \\
\text { granite (3) }\end{array}$ & $7 /+40$ & $\begin{array}{l}0806363 / 78 \\
49503\end{array}$ & 1328 & 25 & 7.2 & $\begin{array}{l}\mathrm{Pb}, \mathrm{Ni}, \mathrm{Cr} \\
\mathrm{Fe}, \mathrm{Al}, \mathrm{Ca}\end{array}$ \\
\hline $\begin{array}{l}\text { Gibbsite } \\
\text { (Aluminium) (3) }\end{array}$ & $8 /+40$ & $\begin{array}{l}0805566 / 78 \\
49190\end{array}$ & 1418 & 26 & 6.5 & $\begin{array}{l}\mathrm{Pb}, \mathrm{Al}, \quad \mathrm{Cu}, \\
\mathrm{Zn}, \mathrm{Ni}, \mathrm{Mg}\end{array}$ \\
\hline $\begin{array}{l}\text { Alluvial } \\
\text { deposits/ } \\
\text { decomposed } \\
\text { granite (3) }\end{array}$ & $9 /+40$ & $\begin{array}{l}0803014 / 78 \\
48374\end{array}$ & 1462 & 26 & 7.2 & $\underset{\mathrm{Ca}}{\mathrm{Ni}, \mathrm{Cd}, \mathrm{Pb},}$ \\
\hline $\begin{array}{l}\text { Ferrugenous } \\
\text { sandstones (3) }\end{array}$ & $10 /+40$ & $\begin{array}{l}0794805 / 78 \\
57494\end{array}$ & 1455 & 25 & 6.9 & $\begin{array}{l}\mathrm{Fe}, \quad \mathrm{Cr}, \mathrm{Ni}, \\
\mathrm{Fe}, \mathrm{Ca}\end{array}$ \\
\hline $\begin{array}{l}\text { Ferrugenous } \\
\text { sandstones (3) }\end{array}$ & $11 /+40$ & $\begin{array}{l}0800197 / 78 \\
52163\end{array}$ & 1451 & 26 & 7.1 & $\begin{array}{l}\mathrm{Fe}, \mathrm{Cr}, \mathrm{Ni}, \\
\mathrm{Ca}, \mathrm{Mg}\end{array}$ \\
\hline
\end{tabular}

\section{Materials and Methods}

An environmental monitoring approach was used to determine and measure toxic heavy metal concentrations in ground water samples collected monthly from 12 selected boreholes situated in areas with varied land uses in the study area. The number of boreholes selected for the analysis per sub-catchment depended on the dominant type of land use, geology and borehole depth in excess of 40 metres. Each borehole needed to have a quantified water yield and an initial recording 
higher than the normal acceptable levels of identified toxic heavy metals.

With the aid of a global position system receiver, boreholes in each sub-region were georeferenced, height above mean sea level recorded and distance between each borehole and gradients calculated to determine direction of ground water flow based on borehole depths of 40 metres. The ground water hydraulic conductivity values for the three sub regions in the study area were provided by ZINWA as shown in Table 2 .

Table 2: Borehole numbers and site locations, hydraulic conductivity measurements, height above mean sea level (m), length of area parallel to flow and gradients by sub-region

\begin{tabular}{lllll}
\hline $\begin{array}{l}\text { Borehole numbers and site } \\
\text { locations }\end{array}$ & $\begin{array}{l}\text { Hydraulic } \\
\text { conductivity } \\
\left(\mathrm{m}^{3} / \mathrm{m}^{2} / \mathrm{hr}^{*}\right.\end{array}$ & $\begin{array}{l}\text { Height above } \\
\text { mean sea level } \\
(\mathrm{m})\end{array}$ & $\begin{array}{l}\text { Length of area } \\
\text { parallel to } \\
\text { flow }(\mathrm{m})\end{array}$ & Gradient \\
\hline $0204577 / 7858814$ & 10 & 1480 & 0 & $1: 15$ \\
$0203944 / 7859546$ & 10 & 1497 & 969.9 & $1: 15$ \\
$0203284 / 7860086$ & 10 & 1499 & 857.9 & $1: 15$ \\
$0189199 / 7850373$ & 20 & 1390 & 0 & $1: 10$ \\
$0189509 / 7852399$ & 20 & 1375 & 2060.9 & $1: 10$ \\
$0185445 / 7856760$ & 20 & 1358 & 5262.3 & $1: 10$ \\
$0806363 / 7849503$ & 15 & 1328 & 0 & $1: 10$ \\
$0805566 / 7849190$ & 15 & 1418 & 857.3 & $1: 22$ \\
$0803014 / 7848374$ & 12 & 1462 & 2681.0 & $1: 22$ \\
$0794805 / 7852163$ & 12 & 1455 & 4728.9 & $1: 22$ \\
$0800197 / 7852163$ & 9 & 1451 & 7595.2 & $1: 22$ \\
\hline
\end{tabular}

Source: ZINWA 2010*

Two water samples were collected from each borehole once a month over a period of 24 months. The duration is presumed to cater for the effects of seasonality and pollutant loads A total of two hundred and sixty four ground water samples were collected from the designated boreholes. Samples were collected in plastic containers and immediately transported to the laboratory for analysis. The $\mathrm{pH}$ value for each water sample was recorded using a standard $\mathrm{pH}$ meter. Each ground water sample was subjected to an Atomic Absorption Spectrophotometry analysis for metallurgical assaying. An Atomic Absorption Spectrophotometer Varian SpectrAA-100 was used in the absorption mode to determine concentration levels of each toxic heavy metal in ground water samples. Each ground water sample was subjected to four aspirations to determine the concentration levels of chrome, lead, cadmium and nickel metallic elements. The results displayed by the spectrophotometer were expressed in parts per million (ppm). The concentration load of each toxic heavy metal per water sample was based upon the absorbance of each metallic element under investigation each month.

The analysis was achieved by applying the Dilution-Attenuation Factor (DAF) and the MANN-KENDALL Seasonal Analysis as explained below.

Dilution-Attenuation Factor $(\mathrm{DAF})=\mathrm{I}+\mathrm{Kid} / \mathrm{IL}$.

Where, $\mathrm{i}=$ gradient

$$
\begin{aligned}
& \mathrm{d}=\text { depth of borehole } \\
& \mathrm{I}=\text { infiltration rates }(\mathrm{m} / \mathrm{yr}) \\
& \mathrm{L}=\text { length of area of concer } \\
& \text { ground flow }(\mathrm{m}) \\
& \mathrm{K}=\text { hydraulic conductivity }((\mathrm{m}) \\
& \text { Inferences for each pollutant } \\
& <1=\text { higher concentration } \\
& 1=\text { no dilution } \\
& >1=\text { higher dilution }
\end{aligned}
$$$$
\mathrm{L}=\text { length of area of concern parallel to }
$$$$
\mathrm{K}=\text { hydraulic conductivity }\left(\left(\mathrm{m}^{3} / \mathrm{m}^{2} / \mathrm{hr}\right)\right.
$$

Source: Winter et al.,1998 
Toxic heavy metal concentrations were compared against distance along the contaminant path. Toxic heavy metal load data was disaggregated by season to help eliminate the impacts of seasonal water level variations on contaminant concentrations. A spreadsheet based approach was used with the aid of Microsoft Visual Basic for Application (VBA) within an excel spreadsheet. This tool was used to process the input time series data, perform trend analysis and to report the results. Statistically significant changing trends in toxic heavy metals in ground water were presented visually. Maps were developed to show the spatial temporal distribution of each toxic heavy metal in ground water supplies in upper Sanyati catchment. Heavy metal contaminant levels recorded from the study area were compared with the World Health Organization (WHO) maximum contaminant limits to determine the suitability of the ground water supplies for domestic consumption.

\section{Results and Discussion}

Figures 2 and 3 display the predicted spatial concentration levels of each of the toxic heavy metal for the dry and wet seasons respectively.

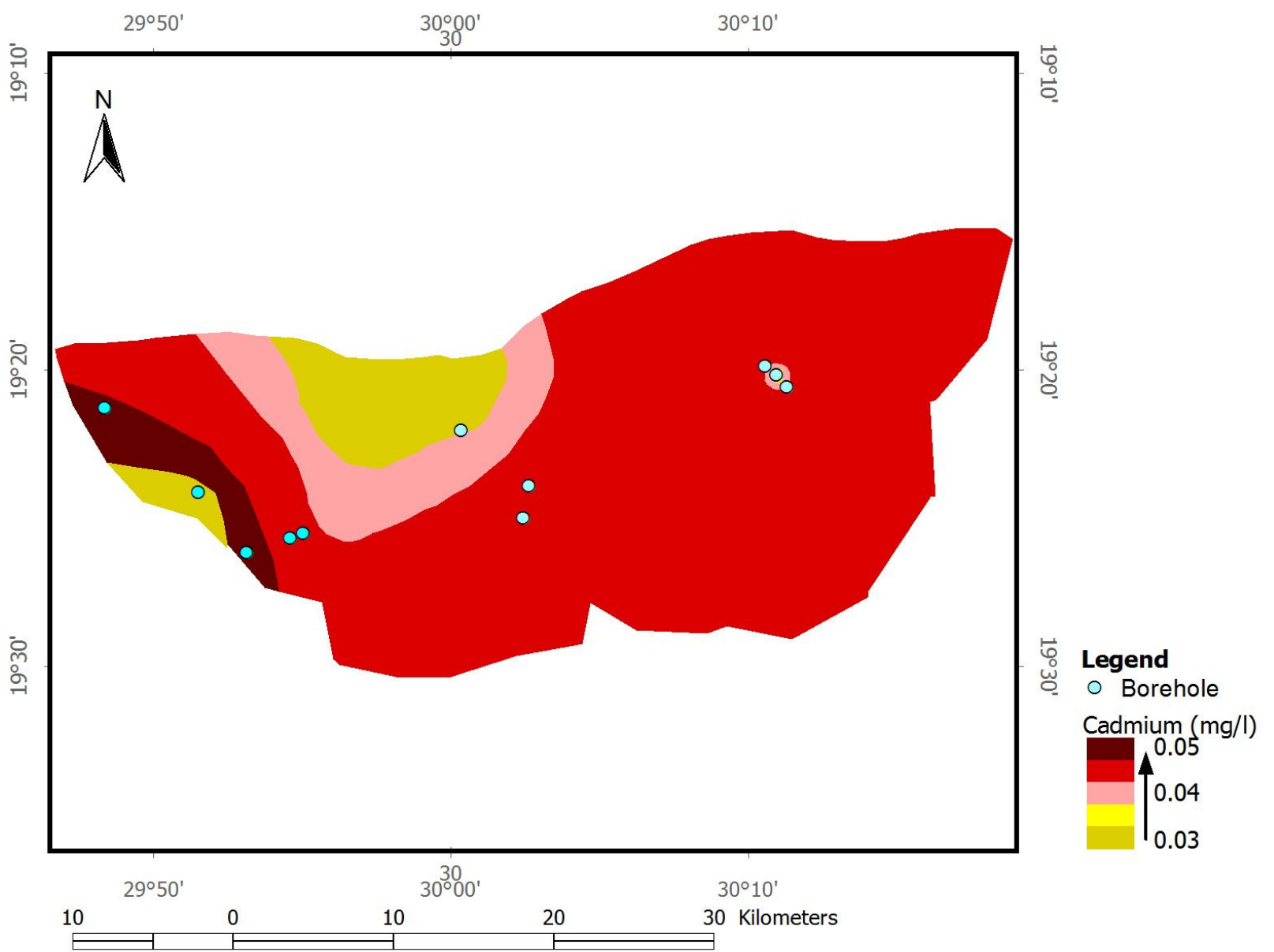

Figure 2: Dry season Cadmium pollution risk prediction in upper Sanyati catchment

During the dry season (April to September) ground water cadmium values ranged between 0.04 and $0.05 \mathrm{mg} / \mathrm{L}$ were recorded in the study area. High values were recorded in boreholes adjacent to intensive cattle and chicken producing areas but decreasing eastwards where mining and mineral processing activities are predominant. 


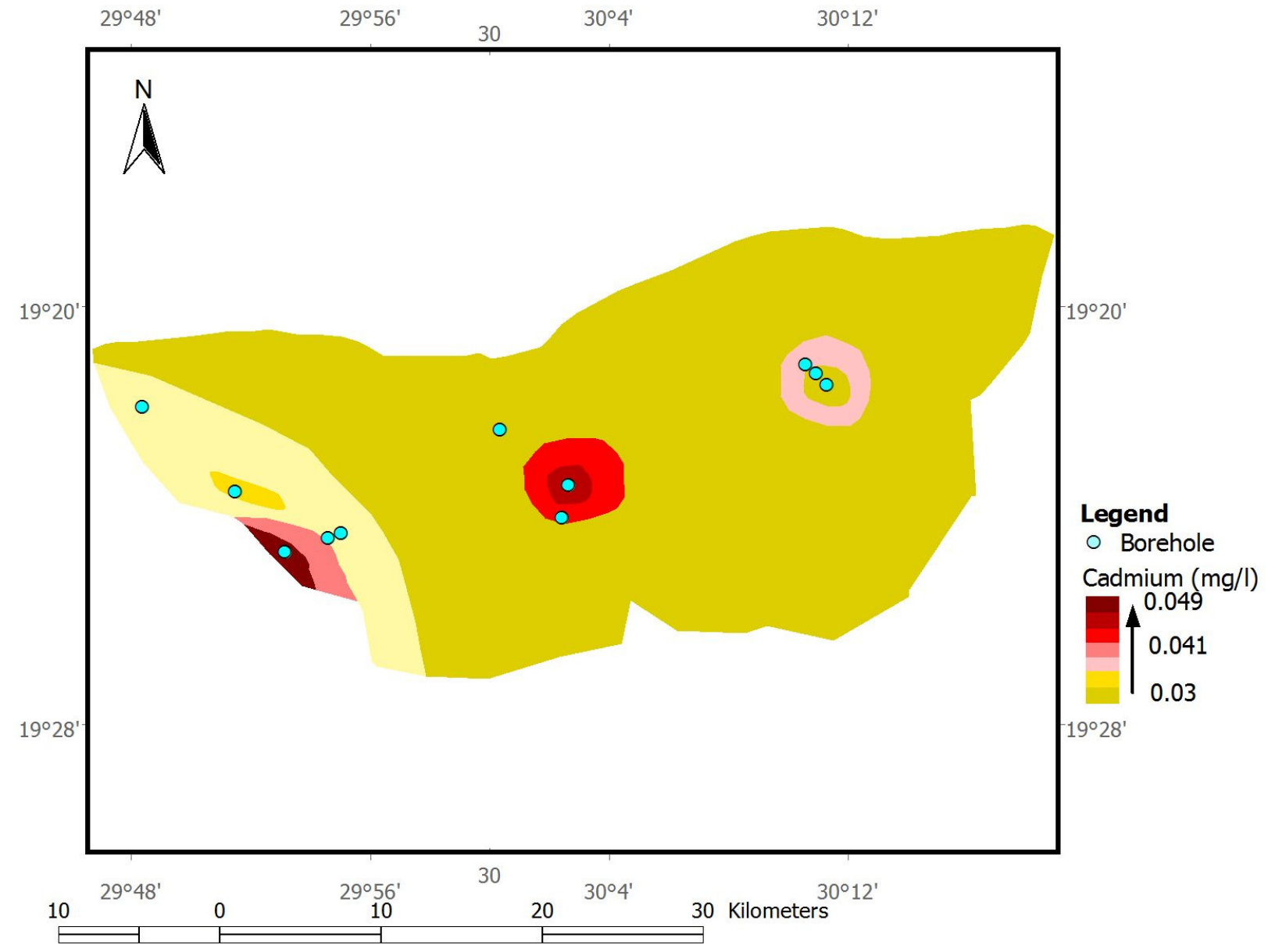

Figure 3: Wet season Cadmium pollution risk prediction in upper Sanyati catchment

During the wet season ground water cadmium content is more localized with high concentrations recorded in areas where there is intensive livestock farming, Hwahwa sewage disposal site and along the Great Dyke. Lithologically, in areas covered by ferruginous sandstones and phyllo-silicates cadmium abundance was noted. Movement of cadmium in the subsurface environment showed that cadmium plumes result from acidic conditions and presence of organic compounds that form soluble cadmium. The seasonal spatial cadmium variations in the study area were also due to varying point sources of contamination attributed to specific land uses. For instance, boreholes located close to cattle feedlots and in chicken producing areas had the highest cadmium concentrations. Based on the World Health Organization limit for cadmium $(0.003 \mathrm{mg} / \mathrm{L})$ only borehole 5 in sub-region 2 and boreholes 9 and 12 in sub-region 3 exceeded the maximum cadmium contaminant levels by a factor of 0.01 . 


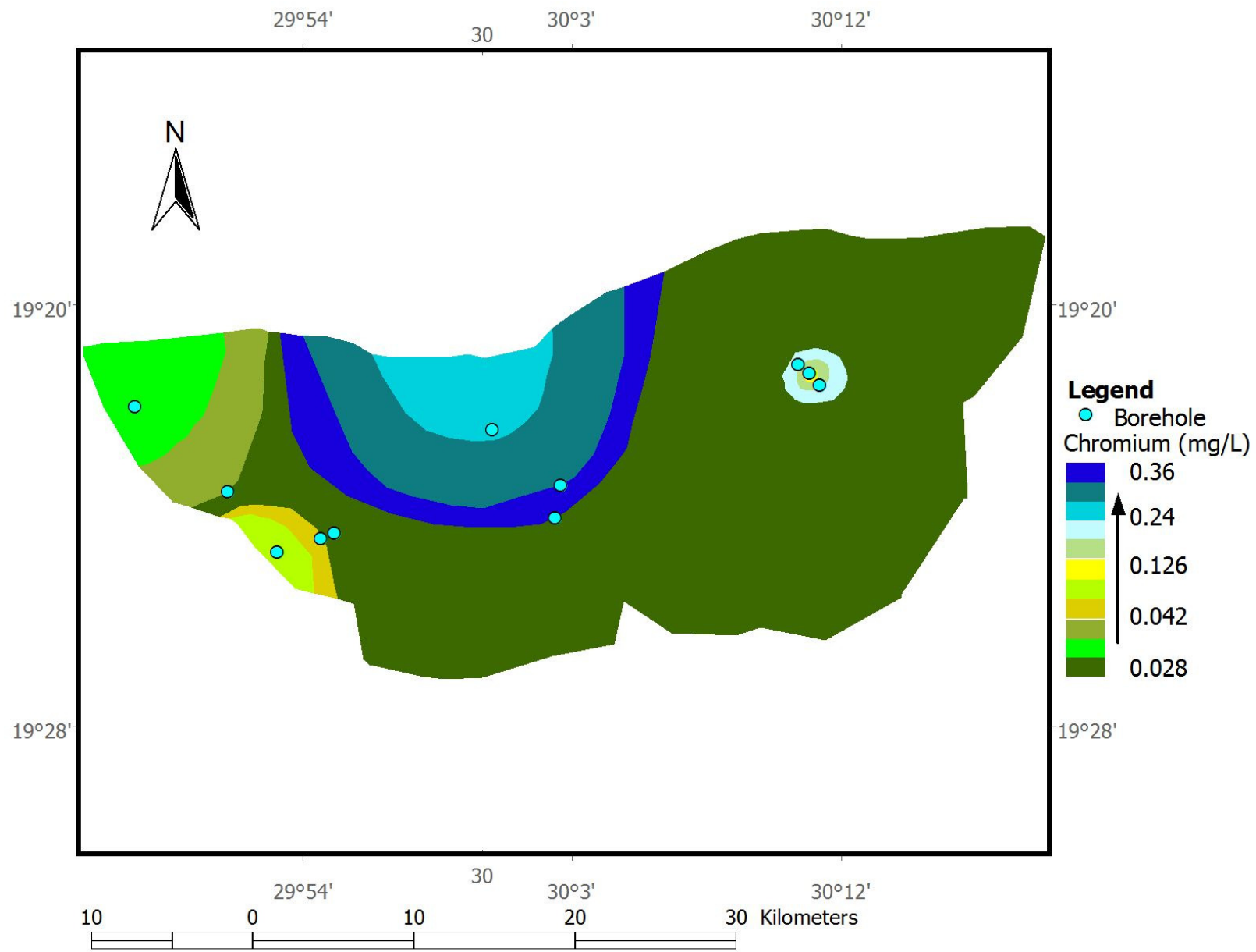

Figure 4: Dry season Chromium pollution risk prediction in the study area in upper Sanyati catchment

Chrome distribution in ground water in the study area was widespread but decreased towards the north-west. Chrome levels between $0.24 \mathrm{mg} / \mathrm{L}$ and $0.36 \mathrm{mg} / \mathrm{L}$ were recorded during the dry season in boreholes 1, 2 and 3 in sub-region 1 and boreholes riparian to Kwekwe River and its tributaries. Ground water chrome enrichment in these areas may be attributed to effluent discharges and dispersion of mine wastes into the surrounding environment and also the oxidation of sulphide chrome ores that are exposed to weathering. 


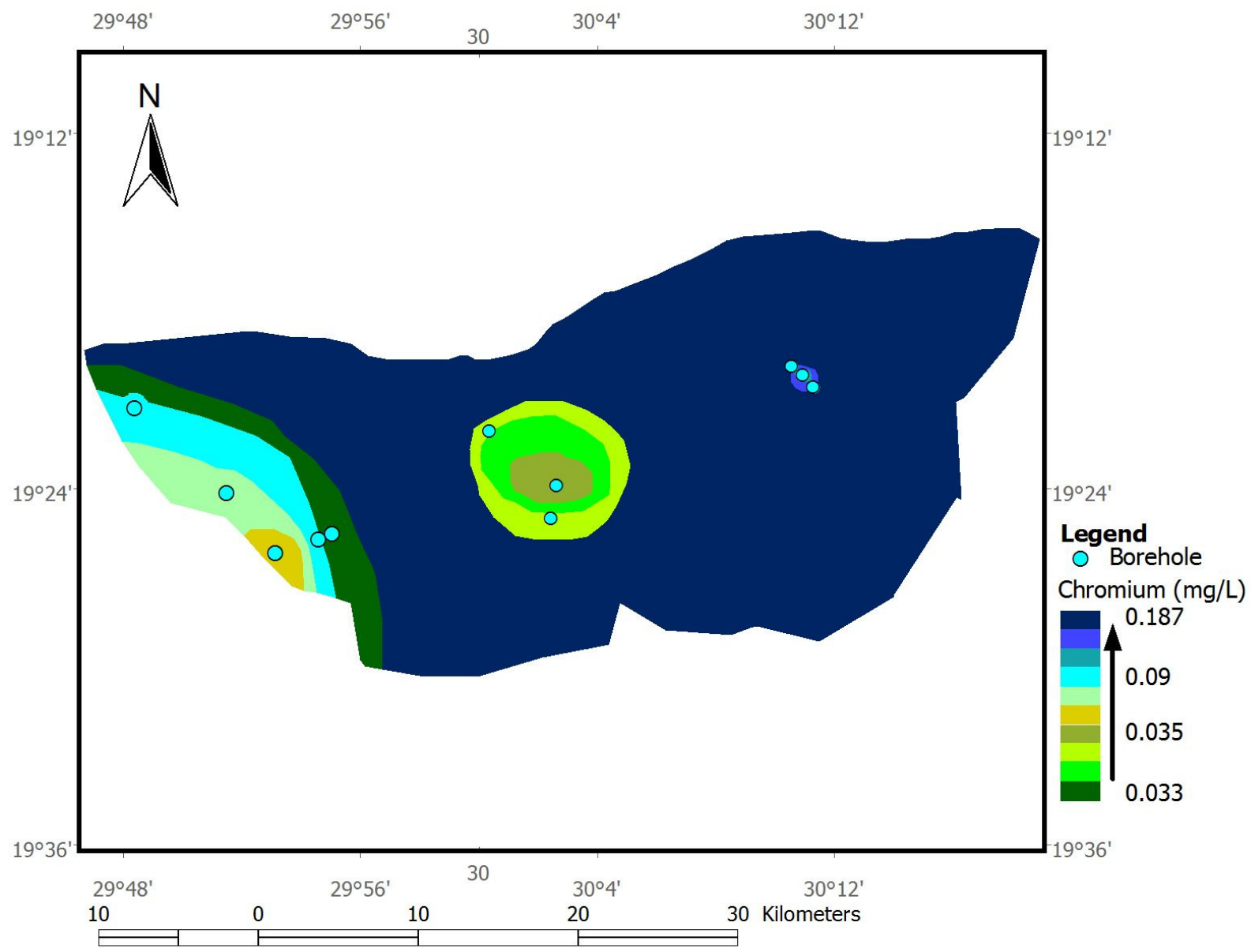

Figure 5: Wet season Chromium pollution risk prediction

During the wet season (October -March) ground water chrome is more widespread with its concentration levels lower than in the dry season. As water soaks into the soil and passes downwards in the subsystem; it reacts with chrome while also dissolving other solid minerals in the ground reducing its concentration levels. By comparison, in the dry season (April to September) there are limited volumes of ground water coming into contact with chrome decreasing its chances of dissolving and spreading over a wider area hence the high dry season concentrations. Overall, the chrome level in ground water was within the WHO drinking water safe limits except for boreholes 1, 2 and 3 in sub-region 1 and borehole 7 in sub-region 3 . 


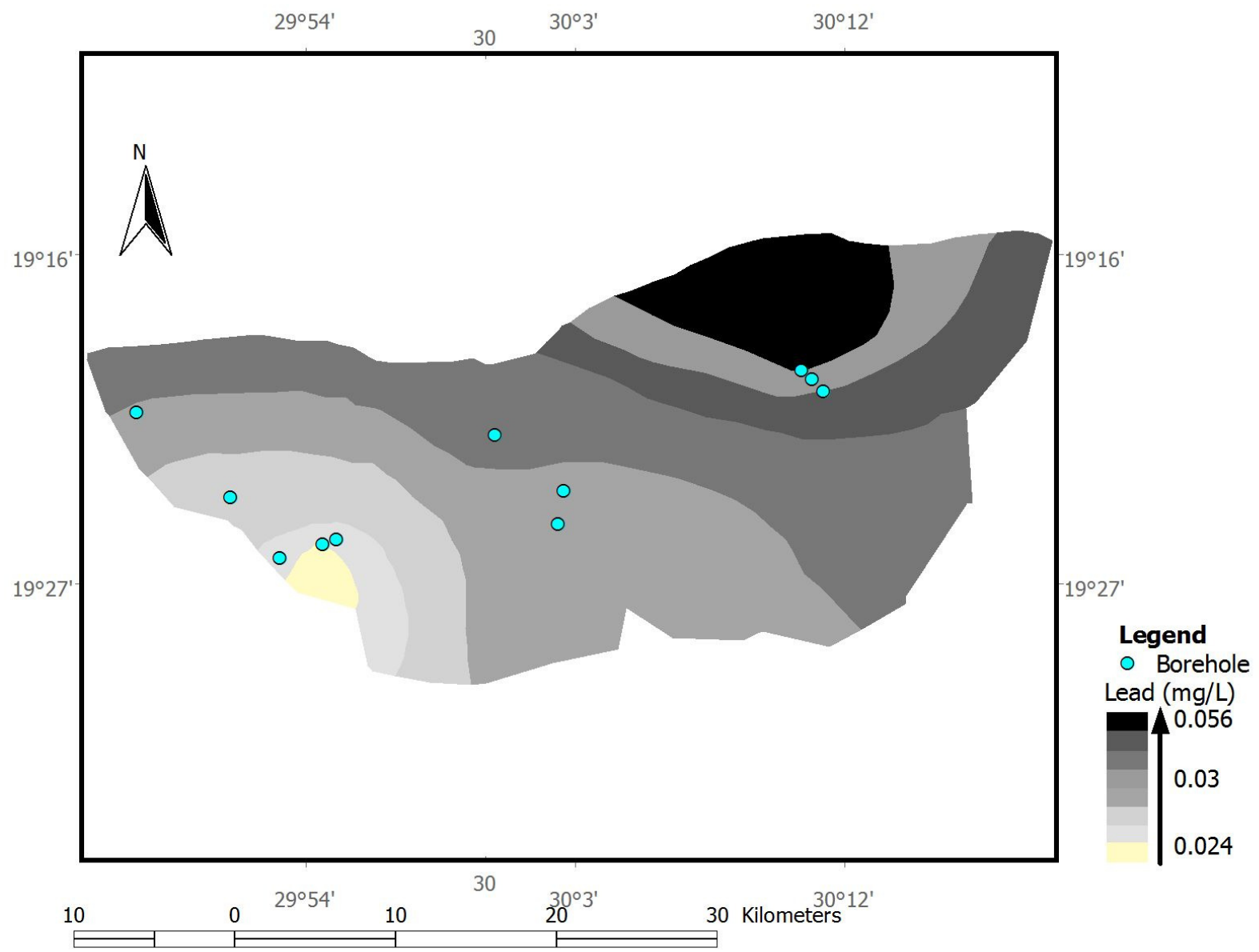

Figure 6: Dry season lead pollution risk prediction

Lead concentrations in ground water of between $0.03 \mathrm{mg} / \mathrm{L}$ to $0.056 \mathrm{mg} / \mathrm{L}$ were present in fairly narrow formations. The lead content increased northwards following the maximum dip of the study area in the catchment. The presence of high concentrations of lead in the ground water throughout the broader area of the study area could have been due to mobilization by low $\mathrm{pH}$, precipitation and ground water flow towards low gradients. This spatial spread could also be linked to chrome ore wastes in sub-region 1 whose crystallization reactions may be contributing to lead enrichment northwards towards low lying areas of the study area. 


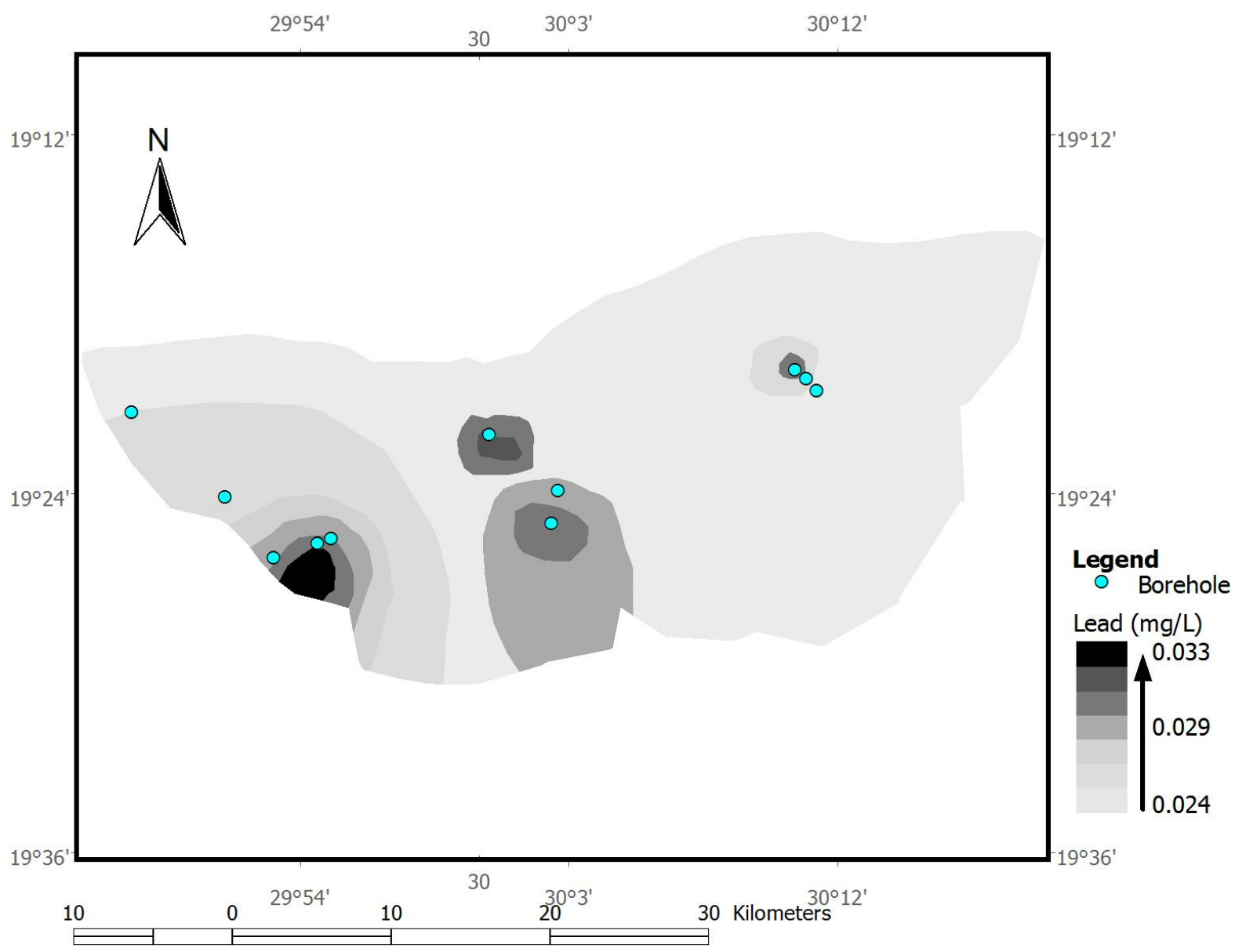

Figure 7: Wet season Lead pollution risk prediction in the study area in upper Sanyati catchment

Localized lead content at between $0.029 \mathrm{mg} / \mathrm{L}$ and $0.033 \mathrm{mg} / \mathrm{L}$ was recorded during the wet season in water from boreholes 1, 4, 6, 7 and 8. On a comparative basis lead content in ground water was higher and more widespread during the dry season than the wet season. The distribution could be linked to low $\mathrm{pH}$ values recorded during the dry season and from atmospheric deposition. High lead content observed in water drawn from: boreholes, 1 and 2 situated in chrome mining areas, borehole 4 located in a cement quarrying area, borehole 6 close to Hwahwa Prison complex and Gweru-Mvuma highway and boreholes 7 and 8 near Gweru City suggested anthropogenic sources as an additional cause. For both seasons, water from all boreholes that were under observation had a lead content that was higher than the World Health Organization $0.01 \mathrm{mg} / \mathrm{L}$ limit. 
Predicting Toxic Heavy Metal Movements in Upper Sanyati Catchment................MADEBWE et al.

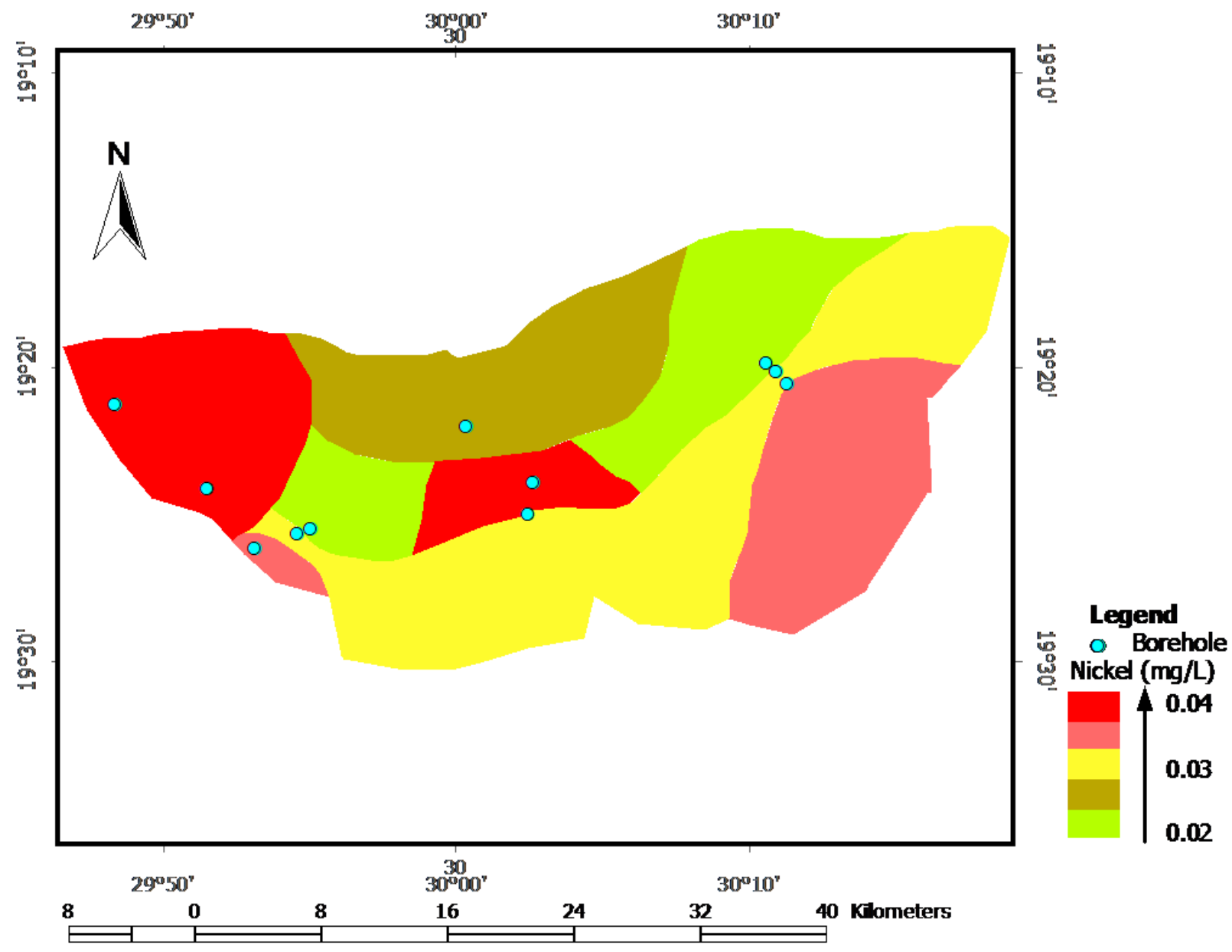

Figure 8: Dry season nickel pollution risk prediction

The ground water nickel concentrations of between $0.03 \mathrm{mg} / \mathrm{L}$ and $0.04 \mathrm{mg} / \mathrm{L}$ are present in areas overlain by ferruginous sandstones in sub-region 3, clay soils in sub-region 2 and basaltic rocks in sub-region 1 . Nickel content in ground water in the study area could be linked to both point and non-point sources. Elevated nickel levels were due to dumping of sewage sludge and agricultural activities associated with phosphate fertilizer applications in sub-regions 1 and 2. In sub-region 3, ground water nickel sources could be due to use of fossil fuels originating from Gweru City's industrial and agricultural wastes disposal sites. Overall, water in $50 \%$ of all the boreholes had nickels levels that were higher than the WHO limits of $0.02 \mathrm{mg} / \mathrm{L}$ (Adelekan and Abegunde, 2011). 


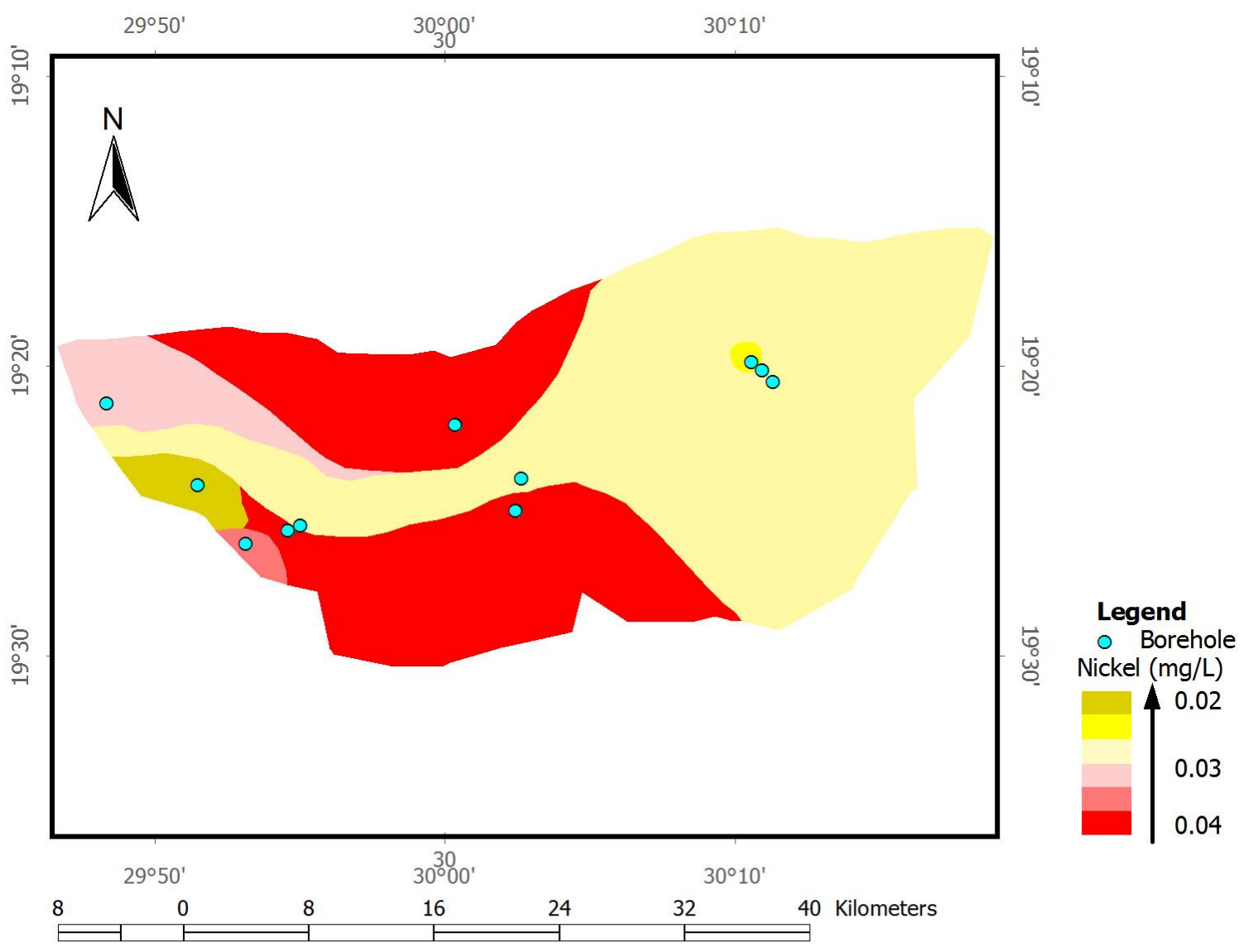

Figure 9: Wet season nickel pollution risk prediction

Nickel content at between $0.03 \mathrm{mg} / \mathrm{L}$ and $0.04 \mathrm{mg} / \mathrm{L}$ was also recorded during the wet season in boreholes $4,6,7,8$ and 9. On a comparative basis nickel content in ground water supplies is more widespread during the wet season than the dry season. The distribution could be linked to low $\mathrm{pH}$ values recorded during the dry season and from atmospheric deposition from urban effluents. Only $25 \%$ of all the boreholes had water whose nickel content was higher than the World Health Organization limit.

\section{Conclusion}

The general behaviour of toxic heavy metals tested in the ground water varied depending on the parameter that was tested. Variations in toxic heavy metals in ground water upper Sanyati catchment were influenced by both geogenic and anthropogenic activities. In areas where silicate mineral crystallization reactions occur under varying $\mathrm{pH}$ levels, toxic heavy metals sorbed onto soil surfaces and when released, they eventually found their way into ground water supplies causing uneven distribution in the study area. When chrome, lead, cadmium and nickel contaminant values were compared with WHO standard limits for drinking water, it was observed that all the four toxic heavy metals were above the maximum recommended permissible limits. Exposure risks to humans from toxic heavy metals in upper Sanyati catchment were dependent upon the solubility and bioavailability of these contaminants in soil and ground water. 


\section{References}

Adelekan, B.A. and Abegunde, K.D. (2011). Heavy metal contamination of soil and ground water at automobile mechanic villages in Ibadan, Nigeria. International Journal of the Physical Sciences vol 6 (5): 1045-1058.

Basta, N.T., Ryan J.A. and Chaney, R. (2005). Trace elementary chemistry in residual- treated soil: Key concepts and metal bio-availability. J. Environ. Qual. 34: 49-63.

Bolan, N.S., Adriano, D.C. and Mahimairaja, S. (2004). Distribution and bioavailability of trace elements in livestock and poultry manure byproducts. Critical Reviews in Environmental Science and Technology. 34: 291-338.

Brassington, R. (1988). Field hydrogeology. Geological Society of London Handbook Series. Open University Press, London.

Cooper, G.R.C. (2002). Oxidation and toxicity of chromium ultramafic soils in Zimbabwe. Applied Geochemistry 17(8): 981-986.

Department of Geography and Environmental Studies. (2012). Physiographic features and land uses of upper Sanyati Catchment. Midlands State University, Gweru.

Eary, L.E. and Rai, D. (1998). Chromate removal from aqueous wastes by reduction with Ferrous ion. Environmental Science and Technology 22:972-977.

EPA. (1994). Modelling approach for simulating three-dimensional migration of land and disposal leachate with transformation products and consideration of water-table mounding. Office of Solid Waste.
Harter, T. (2005). Ground Water Quality and Pollution. http://anrcatalog.ucdavis.edu accessed on 10/06/2012.

IUCN. (1994). Guidelines for Protected Area Management Categories, IUCN, Gland, Switzerland.

Klee, R.J. and Graedel, T.E. (2004). Elemental cycles: A Status Report on Human or Natural Dominance. Annu. Rev. Environ. Resour. 29: 69-107.

Kusky, T.M. (1998). Tectonic Setting and Terrain Accretion of the Archean Zimbabwe Craton. Geology 26: 163166.

Luo, L., Ma Y., Zhang S., Wei, D and Zhu Y.G. (2009). Inventory of trace element inputs to agricultural soils in China. Journal of Environmental Management, 90: 2524-2530.

Ministry of Environment and Natural Resources (2009). Existing Water Quality Control Measures. Government Printers, Harare.

Todd, D.K. (1980). Groundwater hydrology. John Wiley and Sons, New York.

United Nations. (2000). Millennium Development Goals on Water. United Nations: New York.

Wilson, A.H. and Prendergast, M.D. (2001). Platinum Group Element Mineralization in the Great Dyke, Zimbabwe and its Relationship to Magma Chamber Structures. South African Journal of Geology 104: 319-342.

Wright, G. (1997). QSC graphs: A tool to assist aquifer classification. The GSI Ground water Newsletter, 32.

ZIMSTATS (2010). Zimbabwe Environmental Statistics Report. ZIMSTATS, Harare.

ZINWA (2009). Aquifer Transmissivity and hydraulic conductivity values. ZINWA Report, Gweru.

ZINWA (2010). Annual Reports. ZINWA, Harare 